\title{
If the Peer Review Attack Fails, Attack Something Else
}

\section{Jay P. Greene, Manhattan Institute for Policy Research Paul E. Peterson, Harvard University}

In Edward Muir's original article, "They Blinded me with Political Science: On the Use of Nonpeer Reviewed Research in Education Policy," he wrote: "To present to the general public research that has not endured the scrutiny of peer review . . ., while all the time calling the work 'political science,' is a challenge to the very nature of our enterprise as a community of scholars and citizens." In his reply to our rejoinder, this same author, presented with evidence that he himself releases research into the public domain without its first having been reviewed by peers, tacitly retracts his original ethical principle. He now claims only that "social scientists should take special care." He still objects to our research, but now does so on the grounds that it was not done with "special care." But if that is all that he is claiming, then why did he not originally write a critique of our research? Why did he bring up peer review in the first place?

Consider exactly what Muir has explicitly or tacitly conceded in his response to our essay.

1. Greene, Peterson, and Du's research has been published in a peer-reviewed journal-and also in an edited collection that received peer review. Evidently, other scholars thought our research conformed to social science standards and was written with appropriate care.

2. The American Federation of Teachers (AFT), the organization for which Muir works, releases into the public domain research that has not been peer reviewed.

3. Muir himself is the coauthor of at least one research report released into the public domain that has not received peer review.

4. Studies of school vouchers by other well-known academics have for many years been released into the public domain prior to being peer reviewed. (Muir had implied in his initial essay that ours was the "first.")

5. Political science research, including important policy-relevant studies by Robert Putnam and Frances Fox Piven, is often released prior to peer review.

Having conceded virtually the entire argument, how does Muir now try to sustain his position? His syllogism takes the following form: To maintain our enterprise as a community of scholars, substandard, irresponsible research needs to be peer reviewed before being released into the public domain. Peterson, Greene and Du's work is statistically flawed and therefore is an example of substandard research irresponsibly released into the public domain prior to peer review. Therefore, their work challenges "the very nature of our enterprise as a community of scholars and citizens."

To develop this unique claim, Muir first introduces the Orwellian distinction between responsible research and substandard, irresponsible research. Muir begins this line of argument by saying that the phrase placed in the ellipses in the passage quoted above was, in fact, at the very heart of his disagreement with us. The missing phrase runs as follows: "and whose statistical results have not been held to the standards established by the scientific community." We had deleted this phrase because it seemed a distraction, but Muir, complaining that he was quoted out of context, now tells us "it is here that the heart of my disagreement with Greene and Peterson over the irresponsible use of unvetted research can be found." But, of course, if this phrase is a crucial qualifier to Muir's assertions about peer review, then Muir is say- ing that research which is up to standard need not be peer reviewed, but anything substandard and irresponsible does need peer review.

Any reader of John Stuart Mill's "On Liberty" can pick apart this strange argument. Who is to decide which research is irresponsible and therefore must be peer reviewed before the public is allowed to see it?

But even if one were to accept this, the first part of Muir's syllogism, his argument collapses because he fails to prove the second partnamely, that our research was substandard. If not up to standard, why was it accepted for publication in two peer-reviewed publications? Moreover, John Witte and Cecilia Rouse, the latter with whom we shared our underlying data set, both obtained essentially the same findings as we did when they employed our methodology. Even when Rouse took another analytical tack, she got virtually the same substantive results in math (though not in reading).

To bolster his claim about the quality of our research, Muir offers only a series of ad hominem attacks and a hodge-podge of unwarranted methodological criticisms. Muir's ad hominem claims are twofold. ${ }^{2}$ First, he accuses us of drawing policy implications from our research findings. But this hardly distinguishes our research from that of others who study school vouchers, such as John Witte and Cecilia Rouse, whose work Muir specifically applauds. Similarly, scholars who study campaign finance, social capital, or welfare reform include policy recommendations both within their publications and in separate commentary. $^{3}$

Second, Muir says our research is funded by foundations that have boards and staffs with political points of view. If that is a basis for 
concluding that a piece of research is substandard and irresponsible, then virtually all foundation-funded research, not to mention research funded by the AFT, is flawed. Few, if any, foundations are led or staffed by political eunuchs. If Muir is suggesting that research funded by antivoucher foundations is responsible and of high quality, while research funded by provoucher foundations is not, ${ }^{4}$ then he will persuade only those who have already joined his cause.

After devoting most of his energy to ad hominem attacks, Muir finally offers a few methodological criticisms, relegating most of them to an endnote. Here he makes three criticisms.

1. Our research inappropriately combined results from students in two cohorts-those that have received three years of a particular type of schooling with those that have received four. Why is this problematic? Social scientists combine adjacent categories to obtain larger numbers of cases all the time. Despite Muir's inaccurate claim that she did otherwise, Rouse, in fact, combined four adjacent years to obtain her results.

2. Our sample suffers from attrition. This does not make a study substandard and irresponsible. Virtually all panel studies suffer from attrition. Certainly all studies of the Milwaukee voucher program suffered from exactly the same problem, because all were dependent upon data sets that contained many missing cases. We acknowledged this limitation in the initial presentation of our findings. But we also showed no significant differences in observable baseline characteristics of surviving mem- bers of test and control groups, which indicates that attrition is an unlikely explanation for our results. Nonetheless, we recommended that carefully designed studies continue to examine the effects of vouchers, a suggestion that is currently being implemented in research now underway in New York City, Washington, DC, and Dayton, Ohio (Peterson et al. 1999; Howell and Peterson 2000; Wolf, Howell, and Peterson 2000).

3. Muir blithely repeats his claim that the inaccurate assertions by voucher-opponent Alex Molnar are correct without any further citation or documentation. In our initial rejoinder we fully dispensed with this issue.

Muir then attempts to distinguish our research from that of Robert Putnam and Frances Fox Piven, saying ours requires peer review but neither Putnam's nor Piven's does, because these scholars do not "dress their theories in science in an effort to legitimize" their conclusions. Instead, Putnam is said to have written an "essay," which was "inspired by observing people bowling alone." Contrary to Muir, the title of Putnam's study is not based on observations of people bowling alone but on information indicating a decline in bowling-league membership. And Putnam's "essay" is hardly the puff piece Muir imagines. Putnam's argument is bolstered by a wealth of quantitative information on falling memberships in voluntary organizations and declining citizen participation rates, information disputed by other social scientists who employ their own scientific "trappings" in unpublished and published papers yet to be peer reviewed.
Nor is Muir accurate in his reading of the work of Frances Fox Piven. She, too, gathered quantitative data that supported her argument that urban disorder enhanced the political power of poor minorities. In short, Muir's attempt to distinguish our research from that of Putnam and Piven does not succeed any better than his effort to distinguish our work from his own and that of his AFT colleagues. If any of these studies need peer review prior to release into the public domain, they all do.

By now it should be clear that Muir was never really attempting to propose a neutral standard of professional conduct. He was simply looking for plausible cover under which he could question the credibility of scholars whose research was not welcomed by the organization for which he works, using the same ad hominem tactics in a professional journal that have been employed by the AFT on its web site and in conversations with reporters. James Coleman was only partially correct when he identified the forces that chill the freedom of scholars to explore the merits of public and private education. Coleman thought it was a general propublic-school consensus that generated personal attacks on dissenting scholars, thereby discouraging young, vulnerable scholars from entering the field. But the direct threat to free inquiry arises not out of a vague consensus, though this might play a secondary role. Rather, it is the result of deliberate actions taken by organized groups with a stake in the status quo.

\section{Notes}

1. Muir also explicitly concedes that the AFT considers discussions of papers at conventions constitute peer review. Accepting the AFT's definition of peer review, our paper received peer review on still a third occasion-as early as August 30, 1996, immediately after the paper was released into the public domain. If Muir's entire complaint is based on the ten-day window between the convention presentation itself and the appearance of the results of our research in The New York Times and other media outlets, then the complaint is hardly worth discussing, especially by Muir who has himself has also released research reports to the media prior to peer review. Moreover, as any reader of the science section of The New York Times can discern, similar advance reports of scientific findings appear prior to their publication elsewhere nearly every Tuesday.

2. Some of Muir's ad hominem arguments are particularly silly. For example, Muir attacks us for a newspaper headline when, as any op ed writer knows, authors do not see headlines prior to their appearance in print. He also attacks us for timing the release of our study when we did. He suggests, without any documentation whatsoever, that we knew what Robert Dole would say in his convention acceptance speech. In fact, we were as surprised as most political insiders that Dole had decided to discuss school vouchers in that address. Our study was released in midAugust, before the late-August APSA meeting, because, as most PS readers know, APSA papers are due August 1. Muir also seems to 
object to the circulation of our findings by groups who favor school vouchers. Why? Is it not desirable that relevant social science research be distributed to policymakers? Muir is upset that The New York Times, the Associated Press, The Wall Street Journal, and others saw our convention paper before it was delivered, but, as discussed in the preceding note that is hardly unusual-in the social sciences no less than in medicine, physics, and biology.

3. Peterson has also drawn policy conclusions from his research on the "race to the bottom" (Peterson 1995). In testimony before Congress, he opposed turning over welfare

\section{References}

Howell, William G., and Paul E. Peterson. 2000. "School Choice in Dayton, Ohio: An Evaluation after One Year" $<$ http://data.fas.harvard.edu/pepg > Presented at the Conference on Charters, Vouchers and Public Education. Program on Education Policy and Governance, Kennedy School of Government, Harvard University, Cambridge, MA. and Medicaid policy to the states on the grounds that each state would try to shift the responsibility for addressing poverty problems to their neighbors. Despite these policy recommendations, no one has yet questioned the propriety of presenting the results of this research to the media, members of the American Political Science Association or, for that matter, the circulation of these findings by liberal interest groups opposed to devolution. Should the rules for studies that support policy conclusions favored by liberal interest groups differ from the rules for findings favored by conservative ones?

Peterson, Paul E, 1995. The Price of Federalism. Washington, DC: Brookings Institution Press.

-, David E. Myers, William G. Howell, and Daniel P. Mayer. 1999. "The Effects of School Choice in New York City." In Eaming and Learning: How Schools Matter, ed. Susan B. Mayer and Paul E. Peterson. Washington, DC: Brookings Institution Press.
4. Peterson's research has been funded by a wide range of government agencies and private foundations-Olin and Bradley, said by some to have a conservative orientation, but also by the U.S. Department of Education, Ohio Department of Education, Twentieth Century Fund, Spencer Foundation, Ford Foundation, Rockefeller Foundation, Russell Sage Foundation, Casey Foundation, Packard Foundation, and several other agencies and foundations generally thought to have quite different political leanings.

Wolf, Patrick, William G. Howell, and Paul E. Peterson. 2000. "School Choice in Washington, DC: An Evaluation after One Year" < http:data.fas.harvard.edu/ pepg $>$. Presented at the Conference on Charters, Vouchers and Public Education. Cambridge, MA: Program on Education Policy and Governance, Kennedy School of Government, Harvard University, Cambridge, MA. 


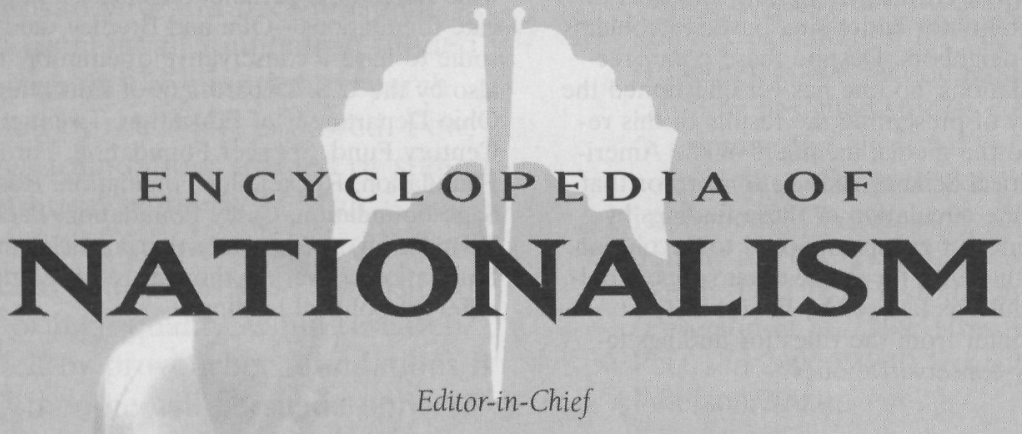

Alexander J. Motyl

Center for Global Change and Governance,

Rutgers University, Newark, New Jersey

"The Encyclopedia of Nationalism fills a serious gap in reference material on one of the most important issues facing the world today. It is an essential tool for scholars, journalists, and public officials."

\section{- JACK F. MATLOCK, JR., GEORGE KENNAN PROFESSOR, INSTITUTE FOR ADVANCED STUDY, PRINCETON, NEW JERSEY}

"Nationalism is a topic as important and fascinating as it is notoriously resistant to comprehensive analysis. Alex Motyl's Encyclopedia of Nationalism avoids the hopeless task of providing an authoritative compendium of what is known or agreed upon. Instead this marvelously illuminating work offers an imaginative and wide-ranging array of outstanding essays. Individually they trace the varieties of assumptions, questions, and answers that scholars from virtually every discipline in the humanities and social sciences have advanced to further our understanding of some aspect of this protean phenomenon. Together they show how rich are the possibilities for joining insights from disparate approaches whose paths of inquiry intersect on the rough terrain of nationalism. As a reference work this is scholarship of a very high order-a must for every college and university library and a valuable resource for specialists."

\section{-IAN LUSTICK, UNIVERSITY OF PENNSYLVANIA}

Nationalism has unexpectedly become a leading local and international force since the end of the Cold War. Long predicted to give way to pannational or economic organizations, nationalism exerts its tremendous force on all continents and in a wide variety of ways. The Encyclopedia of Nationalism captures the aims and scope of this force through a wide-ranging examination of concepts, figures, movements, and events. It is the only encyclopedic study of nationalism available today.

\section{Two-Volume Set}

Prepublication Price: \$350.00*

Fall 2000, c. 1300 pp., $\$ 425.00$ (tentative)/ISBN: 0-12-227230-7

*Prepublication price valid up to three months from publication date.

Visit the Encyclopedia of Nationalism web site for more information at: http://www.academicpress.com/nations/

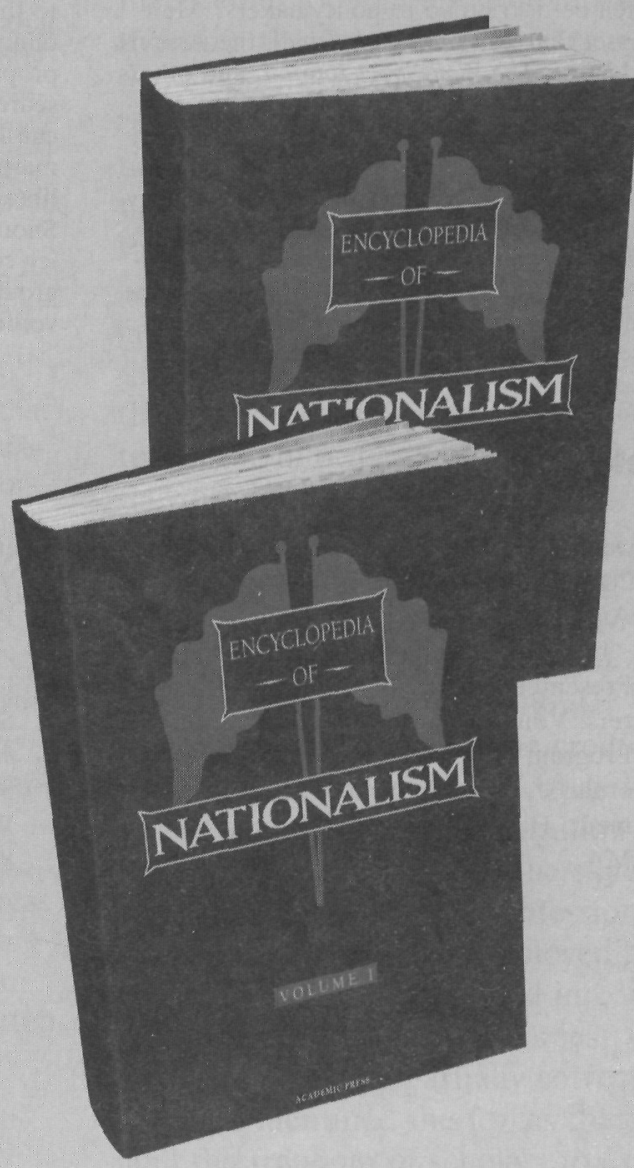

Key Features

- Volume One contains 50 major extended overview essays

- Volume Two features over 500 short articles on the people, ideologies, movements, and events that define nationalism

- Entries cover four major subject areas: Nations and Groups (e.g., Basque Nationalism); Nationalist Leaders (e.g., Mao, Ho Chi Minh); Concepts and Movements (e.g., National Anthems); and Scholars and Thinkers (e.g., Nietzsche, Kipling)

\section{Order from your local bookseller or directly from}

In The U.S. and Canada:

\section{ACADEMIC PRESS}

Order Fulfillment Dept. DM27101

6277 Sea Harbor Drive

Orlando, FL 32887

Call Toll Free: $1-800-321-5068$

Fax: $1-800-874-6418$

E-mail: ap@acad.com
All other countries:

\section{HARCOURT PUBLISHERS LIMITED}

Customer Service Dept.

Foots Cray High Street

Sidcup, Kent DA14 5HP, UK

Tel: +44 2083085700

Fax: +442083085702

E-mail: cservice@harcourt-international.com

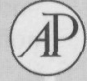

ACADEMIC PRESS

A Harcourt Science and Technology Company
Find us on the web! www.academicpress.com www.harcourt-international.com SECURE ORDERING ONINE

All prices and publication dates subject to change without notice. $\odot 2000$ by Academic Press. All Rights Reserved. $M C / N A / S B E-22030$ sp $3 / 00$ 